\title{
Verbal Violation toward Women: The Portrait of Current Social Reality in DKI Jakarta
}

\author{
Ike Revita $^{1}$, Rovika Trioclarise ${ }^{2}$, Nila Anggreyni ${ }^{3}$ \\ \{revita_ike@yahoo.com ${ }^{1}$, lisefauzi@yahoo.co.id ${ }^{2}$, nilaanggreiny@gmail.com ${ }^{3}$ \} \\ Universitas Andalas, Padang, Indonesia ${ }^{1}$, Poltekkes Kemenkes RI III Jakarta, Indonesia ${ }^{2}$, Universitas \\ Andalas, Padang, Indonesia ${ }^{3}$
}

\begin{abstract}
DKI Jakarta as the capital city of Indonesia bears in very complex problems. The problems are not only related to the economy but also social aspects. One of them is the violation toward women. Among many kinds of violation toward women, verbal one is very hard to be identified since it left nothing physically. This article is aimed at describing the verbal violation experienced by women in DKI Jakarta. The research is conducted in three areas in Jakarta, Jakarta Timur, Jakarta Selatan, and Jakarta Barat. There are 50 wives and widow as the victims of violation to be the respondents. The data are any utterances uttered by (ex) husbands categorized as a violation. Note-taking, recording, and interviewing is done to collect the data. Referential and pragmatic identity method related to the concept of proposed by Smith (2012) is used to analyze the data. The result of the analysis is presented narratively and descriptively. Having analyzed the data, it is found that there are two general forms of verbal violation suffered by women in DKI Jakarta. They are 1) verbal action --(a) intimidation and (b)being called by indecent addressee and 2) non-verbal action--(a)being isolated from friends, family, and society; (b)being gazed at; (c) being ignored.
\end{abstract}

Keywords: Violence, Women, Psychical Violence.

\section{Introduction}

Violence against women is defined as any act of gender-based violation that results in or is likely to result in physical, sexual, or psychological harm or suffering to women, including threats of an act such as coercion or arbitrary deprivation of liberty whether occurring in public or private life [1], [2]. This physical, sexual, or psychological suffering is sometimes ignored since some women regard it as the common thing in the circle of husband and wife's life.

As the husband and wife, the incompatibility regarding idea, plan, or perspective is prevalent. However, the problem comes up as this incompatibility is manifested to illogical and improper ways. One of them is doing the violence. Even, woman as the wife is the one who is under the responsibility of her husband. The welfare of the family, the health, and the security are things that must be provided by the husband to his family.

The one who must protect, love, and keep this woman does inhuman action. He violates his wife. Whatever the reason, this action is humanely unaccepted.

$15 \%-78 \%$ of women became the victims of the violence of their partners in the world. This is possibly ended by the death [3]. Some countries like the USA, Canada, South Africa, Israel, and Australia are regarded as high in violating women [1] [4][5]. Even in Colombia, one 
woman is killed every six days caused by violence. It is estimated that 5-6 women are potential to be the victims of violence in the world [6] .

In Indonesia, the activities of violence toward women re regarded frequent. The annual women's commission noted [7] that 259.150 violence toward women occurred in which domestic violence was in the highest percentage, $60 \%$.

The activities of violence toward women cannot be ignored. It could be categorized as a crime in humans [8]. Even, it reached the culminated point. This is reflected by many abortions done by the youth [9], the brawl among teenagers [10], and women trafficking [11].

The violence toward women has existed thousands of years ago [12] since human beings existed. Its existence gets grower from time to time. It is like the top of the ice mountain[13]. Many cases seemingly cannot be prevented. It has been published in many printed media as well as television [14]. For example, Yuyun who was raped by fourteen men. She was finally killed and thrown away to the ravine [15].

The above description is a just a small part of the fact of violence toward women [16]. With various kinds of domestic violence, the activities sometimes cannot be identified. Even, some people do not know about the violence itself [17]. For example, when the women are reviled, insulted, or disgraced, they tended to be silent or just regard it common [18]. The lack of understanding and the mindset are assumed as the basic reason for being silent. Thus, the violence regarding verbal toward women is commonly done.

\section{The objective of the Writing}

This writing is aimed at describing the phenomena of verbal violation toward women. The objective is to identify the kinds of verbal violence experienced by women.

\section{Methods of the Research}

The research is conducted in DKI Jakarta. There are three cities selected based on the frequency of the occurrence of violation toward women. They are East Jakarta, West Jakarta, and South Jakarta. These three cities are the biggest three of the violence of women [19]. There are 50 respondents who the victims of the violence are questioned-- the wives and the widows. The data are collected by giving a questionnaire. The analysis is done by relating having the concept of verbal violation proposed by [20]. The result of the analysis is presented descriptively [21].

\section{Verbal Violation}

The term of violation toward women variously refers to not only the violation against women [22] but also interpersonal violence [23], or domestic violence [11]. The declaration of elimination of violation against women [1] defined this violation against women as every act against a person, especially women, which results in the emergence of misery or suffering physically, sexually, psychologically, and / or neglected including threats to commit acts, coercion, or deprivation of liberty against the law. This violence can occur in the realm of family or society. Families can refer to husband/wife, and children; people who have a family relationship because of blood, marriage, dairy, care, and guardianship, who live in the household; and/or people who work to help the household and stay in the household.

The practice of the violation against women is the reflection of historically unbalanced power relationship between men and women [24]. Even though, Indonesia has a law that already 
protects women from any kind of violation. The activities of this violation still exist [12] however, the violation toward women increasingly unstoppable [25] inside or outside household which was published in either printed or audio visual media.

The violation against women occurred at society or home/family. This home/family violation is also called as domestic violation [26]. The domestic violation is divided into four. They are a) physical, b) psychological, c) economic, and d) sexual abuse. These four types of violence potentially occur in the domain of household [27].

The most common type of violation toward women beside physic is psychic. The psychic violence is a verbal act of torture (such as humiliating, abusive and dirty) which results in decreased confidence, increased fear, loss of ability to act and powerlessness [28]. This type is not commonly realized. Most women or society regard it as the common thing occurs in the house hold [29]. Some inhumanly verbal dictions are used by the perpetrators of the domestic violence such as the name of animals or a call for a prostitute.

\section{Analysis and Discussion}

The verbal violence toward women occurred in the house hold is generally divided into two. They are verbal action and nonverbal action. The verbal action includes intimidation and the call of the indecent addressee. This can be seen in the following data.

1) Kamu ndak kasih, aku tinggalkan kamu.

'If you do not serve me, I will leave you!

2) Lu harus kerja atau Lu milih jadi janda.

'You must work otherwise you become the widow.'

Such utterances 1 and two are categorized as intimidation. Intimidation means the action that forces other or parties to do something [30]. In intimidation, there is a force which implicitly compels the interlocutors to do. This is what is called as speech act [31]. There is an action in an utterance (the action via performance).

Intimidation is done via utterance. As a husband, he can necessitate his spouse to do what he wants. Even, when the spouse totally depends on him [32]. The husband is of great possibility to ask his wife to do what he likes and to intimidate as it is refused. This is in line with the role and the power of husband and wife at house hold [33]. The power owned by husband is often creating the desire to intimidate or force.

Being called with the indecent addressee is also regarded as a verbal violation. Goblok 'idiot', Pelacur 'prostitute', najis 'excrement', anjing 'dog'and setan 'devil' are the addressee that is used quite often. In some contexts, this term is acceptable since the context becomes the container of an utterance [34][35].

3) Goblok! Goblok! Gini aja ndak becus! 'Idiot! Idiot! It is just not good!

4) Dasar pelacur ndak tau diri...

'What a bitch that does not know yourself...'

5) Woi anjing! Masih aja lu diam. Dasar setan!

'Dog! You are still doing nothing over there.

Satanic!' 
Terms of the addressee are the way how someone addresses others. This term of address depends much on the relationship between the speaker, and the addressee is also relevant as well as how well they know the person being referred to [36].

The diction of words usually conveys information about the social relationships between people as well as about the topic of discussion. However, the use of indecent terms to address the wives in above utterance $3-5$ do not indicate either social relationship or topic. The speaker, in this case, husband, is angry with his spouse. The anger is expressed by choosing thus words goblok, pelacur, anjing, and setan.

The use of these two verbal forms to violate women domestically appears balanced. Though, the indecent terms of the addressee are used more than intimidation-- $55 \%: 45 \%$. This is due to the feeling can be fully expressed through the use of these terms. The occurrence of the indecent terms of addressee and intimidation can be shown in below figure 1.

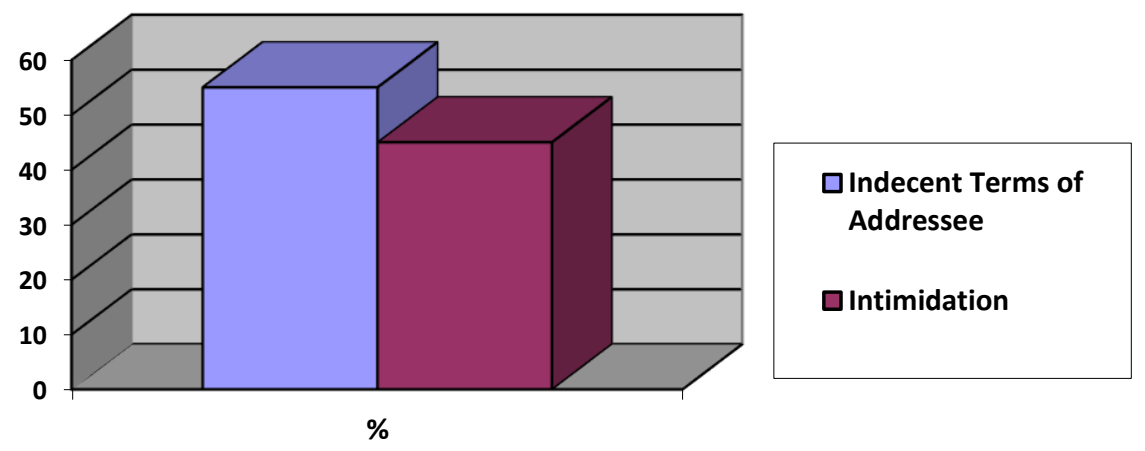

Fig. 1. The occurrence of verbally domestic violation in DKI Jakarta

Some nonverbal actions may also indicate the activities that violate women domestically. For example, is being isolated from friends or family. As the one who has power toward his spouse, a husband possibly dominates the household. Not only regarding power but the domination is also implemented in the domain of economy or daily activity. A wife is often managed economically. The right to regulate the household and spend money to buy food and house hold needs is very limited.

Ironically, the chance to interact and communicate with others like family or society is confined. Every single media to communicate with those outside the home is restricted. The door is locked inside and outside. The wife is seemingly imprisoned. She cannot leave home but with her husband. Furthermore, nobody is allowed to come to his or her home otherwise the husband is at home.

Such isolated treatment is categorized as the violation nonverbally. The right to interact with others is not given due to the power of the husband. This clearly breaks the declaration of human right [32]. Article three of the Declaration of Human Rights states that 'everyone has the right to life, liberty, and security of person. The prohibition of others to intercommunicate or go around is logically unacceptable related to the existence of human beings [37].

Being gazed is another form of nonverbal violation domestically. When doing things wrongly or disobey the order of husband, a wife is probably to be scolded emotionally. This emotion is expressed via facial action--gazing or glaring [20].

This action does not stop because there will be next action did that is a physical violation. This is in line with the cycle of violation toward women with three phases. The conflict between 
the spouses occurs, followed by a physical act like beating or slapping. The victim postpones to ask for help and tries to recover herself. The last phase is the husband apologize and says sorry regrets and promises not to do such action. The women forgive and the situation comes up normally.

The three phases will appear and reappear continuously. It will stop as the reaction done by the victims. Some women victimized domestically by their spouses report to the police or ask protection to women's national commission (Komnas Perempuan) or non-governmental board like Women Crisis Centre Nurani in West Sumatera or Lembaga Bantuan Hukum APIK (Legal Aid APIK) and Koalisi Perempuan (Women's Coalition) in Jakarta. Not all women as the victims of domestic violation do this [14] [18].

The level of education of the perpetrator also becomes the factor leading the violation. Around $47 \%$ of the victims reported to the consulting agency are graduated from university and diploma, and $32 \%$ of their husbands have university level of education. $38 \%$ are those graduated from senior high school, and the rest are from junior and elementary school. It can be seen in the following chart.
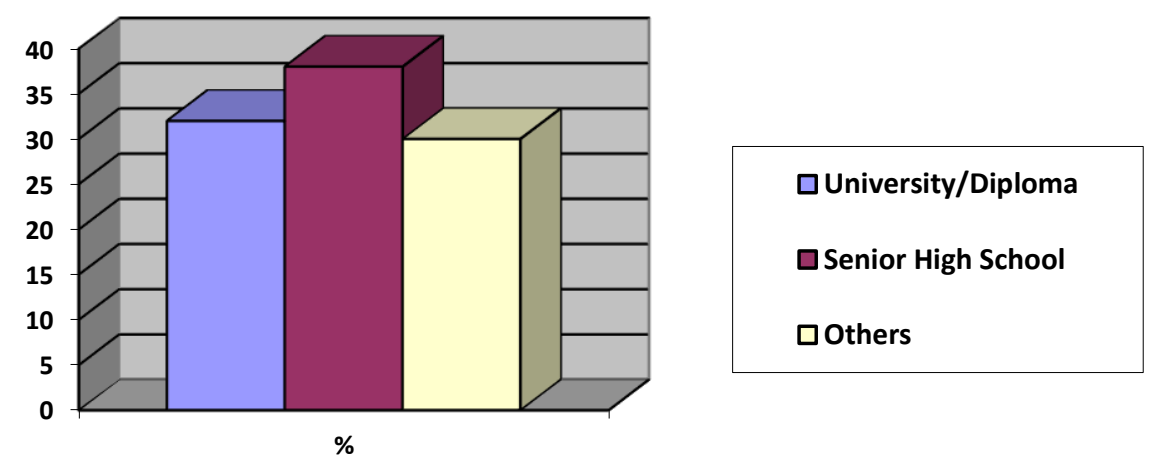

Fig. 2. Educational background of the perpetrator of domestic violence in DKI Jakarta

The education does not guarantee that there will be no domestic violation toward women. The above figure 2 clearly shows that the number of the existence of violation spreads evenly. This indicates that educational background is not only the factor that causes the occurrence of domestic violation toward women in DKI Jakarta. There must be some others that might bring about this violation.

Being ignored is what the women sometimes feel in domestic relations. The spouse does not care about her. Whatever she tells and she feels is disregarded. Even, when getting sick, the woman is still neglected. It can be categorized as nonverbal violation toward women [18][39]. The women feel alone and think nobody cares about them.

When this treatment keeps being accepted by women, it is possible that they are insulted and frustrated. To being insulted and frustration may lead them to a very dangerous situation. They may get depressed and of possibility to commit suicide [18][40].

Figure 3 below shows the consequences of being ignored and the reactions of the victims. $35 \%$ of women are complaining, $20 \%$ are recovering herself and trying to overcome the problem alone, $20 \%$ are only silent, and the rest are others in which suicide is included. These effects cannot be ignored even the number is small[29]. 


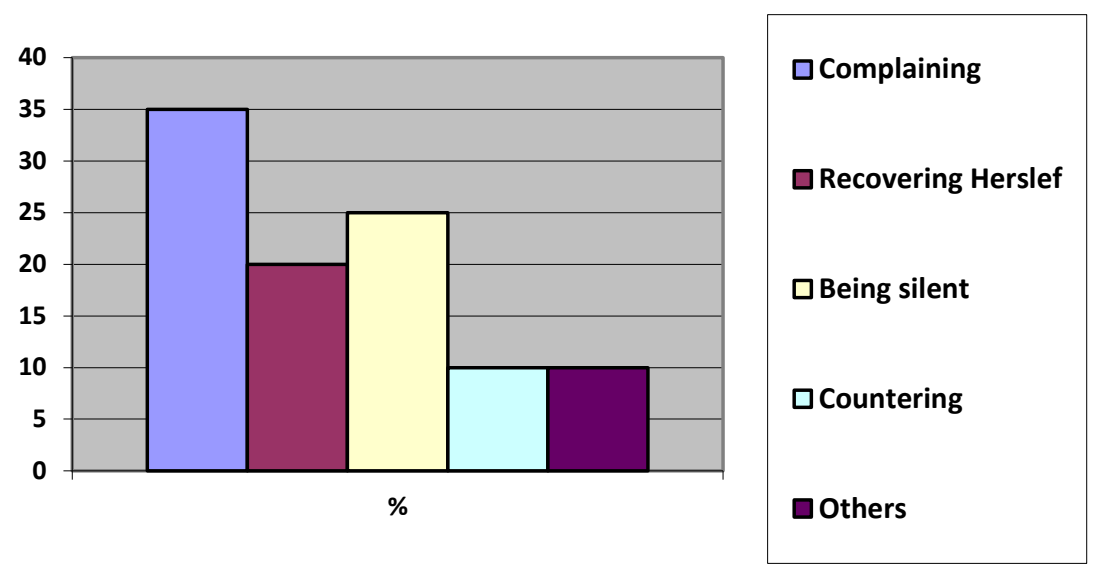

Fig. 3. The effects of being ignored by spouse

\section{Acknowledgment}

I would like to thank DIKTI for funding the research. Thank all the informant and the supporting team of research in DKI Jakarta and West Sumatera. Thank Rector of Universitas Andalas and the Dean of Faculty of Humanities.

\section{References}

[1] U. Nations, "United Nations General Assembly.pdf." United Nations, 1993.

[2] G. Caracci, "Violence against women," Int. J. Ment. Health, vol. 32, no. 1, pp. 3653, 2003.

[3] "United Nations. 2010. The World's Women 2010: Trends and Statistics. Series K, No. 19. Sales No. E10.XVII.11,” no. 19, p. 2010, 2010.

[4] P. S. and B. K., Domestic violence in pregnancy, vol. 4, no. 7. 2001.

[5] "World Health Organization. 2009. Violence Against Women Fact Sheet No 239.pdf." WHO, 2009.

[6] L. Affairs, H. R. Rapporteur, R. Salles, and E. People, "The protection of minors against excesses of sects," no. March, pp. 1-15, 2014.

[7] "Komnas Perempuan . 2016. Lembar Fakta Catatan Tahunan (CATAHU) Komnas Perempuan Tahun 2016. Jakarta: Komnas Perempuan,” p. 2016, 2016.

[8] M. Erikkson, L. Bruno, and E. Nasma, Domestic Violence, Faimly Law and School. London: Macmillan Publishers Limited, 2013.

[9] WHO, "World Health Organization. WHO multi-country study on women's health and domestic violence against women.," p. 2005, 2005.

[10] "Tamtiari, Wini. 2005. Melindungi Perempuan dari Kekerasan dalam Rumah Tangga . Yogyakarta: Kerjasama Ford Foundation dengan Pusat Studi Kependudukan dan Kebijakan Universitas Gadjah Mada.,” p. 2005, 2005.

[11] "Walby, Sylvia. 2004. The Costs of Domestic Violence, Women and Equality Unit. Leeds: University of Leeds,” p. 2004, 2004. 
[12] "Gallois, Wiliam. 2013. The History of Violence in the Early Algerian Colony . New York: Palgrave Mac Millan,” p. 2013, 2013.

[13] I. Revita, Women Trafficking dalam Bingkai Sosiopragmatik.pdf, I, Juli 20. Padang: Visigraf.

[14] SCTV, Laporan Liputan 6 Siang, no. 2. 2013, pp. 1-11.

[15] K. dan N. Komisi Nasional Perlindungan Perempuan dan Anak. Kekerasan terhadap Perempuan Meluas : Negara Urgen Hadir Hentikan Kekerasan terhadap Perempuan di Ranah Domestik, "Kekerasan terhadap Perempuan Meluas : Negara Urgen Hadir Hentikan Kekerasan terhadap Perempuan di Ranah Domestik , Komunitas dan Negara," Lembar Fakta Catatan Tah. 2016, pp. 1-5, 2016.

[16] C. Hagemann-White and H. Rabe, "Combating violence against women Stocktaking study on the measures and actions taken in Council of Europe member States," p. 2006, 2006.

[17] D. B. Krob and L. Steffen, "Religious Influence on Education and Culture: Violence Against Women as Common Sense," Procedia - Soc. Behav. Sci., vol. 174, pp. 2374 2379, 2015.

[18] R. Trioclarise, "Kesehatan Reproduksi Perempuan Korban KDRT." Universitas Indonesia, Jakarta, p. 2013, 2013.

[19] Komnas Perempuan, "Lembar Fakta Catatan Tahunan (CATAHU) Komnas Perempuan Tahun 2017," Lembar Fakta Catatan Tah. Komnas Peremp. Tahun, pp. $1-4,2017$.

[20] Y. Erturk, "Integration of the human rights of women and the gender perspective: violence against women. The Due Diligence standard as a tool for the elimination of violence against women. Report of the Special Rapporteur on violence against women its causes and cons," p. 2006, 2006.

[21] Sudaryanto. 2015. Metode dan Aneka Teknik Analisis Bahasa . Yogyakarta: Sanata Dharma University Press," p. 2015, 2015.

[22] Johnson, Holly, Natalia Ollus and Sami Nevala 2008. Violence against Women: An International Perspective. New York: Springer,” p. 2008, 2008.

[23] J. Walters, Bilingualism. 2004.

[24] Kristi Poerwandari, et al. 2002. Peta Kekerasan: Pengalaman Perempuan Indonesia. Jakarta: Komnas Perempuan,” p. 2002, 2002.

[25] Hakimi, Mohammad, et al. 2001. Membisu Demi Harmoni, Kekerasan Terhadap Istri dan Kesehatan Perempuan di Jawa Tengah, Indonesia. Yogyakarta: LPKGM FK UGM- Rifka Annisa WCC-Umea University-Women's Health Exchange,” p. 2001, 2001.

[26] UU Nomor 23 Tahun 2004 tentang Penghapusan kekekrasan dalam Rumah Tangga." Jakarta, 2004.

[27] Revita, Ike "Terorisme Verbal dalam Aktivitas Women Trafficking di Indonesia," in KOLITA 14, 2015, pp. 1-4.

[28] Kalibonso, R. S. 2002. Kejahatan Itu Bernama Kekerasan Dalam Rumah Tangga. Jurnal Perempuan . Vol 25 (7-21),” vol. 25, p. 2002, 2002.

[29] Revita, Ike, I. S. Wekke, and R. Trioclarise, "Empowering the Values of Minangkabau Local Wisdom in Preventing the Activity of Women Trafficking in West Sumatera," pp. 3-6.

[30] Https://kbbi.web.id/intimidasi, "https://kbbi.web.id/intimidasi." .

[31] E. Oishi, “Austin's Speech Act Theory and the Speech Situation,” Eser. Filos., pp. $1-14,2006$. 
[32] Ulla Carlsson, Regulation, Awareness, Empowerment., vol. 112, no. 12. 2012.

[33] A. Cruse, A Glossary of Semantics and Pragmatics. Edinburgh: Edinburg Unoversity Press, 2006.

[34] K. P. Schneider, Handbooks of Pragmatics Wolfram Bublitz. .

[35] I. Revita, "Matrilinial System and The Activity of Women Trafficking In West Sumatera," pp. 2001-2003, 2012.

[36] J. Holmes, An Introduction to Sociolinguistics. London and New York: Taylor and Francis Group, 2013.

[37] S. Violence, Domestic and Sexual Violence and Abuse. .

[38] S. E. Yuarsi, "Tembok Tradisi dan Tindak Kekerasan Terhadap Perempuan,” p. 2002, 2002.

[39] Revita, Ike and R. Trioclarise, "Medical-Pragmatics Analysis Of Activities Of Women Trafficking In West Java : Portrait of the Victims," no. 2012, pp. 1-4, 2017. 